\title{
Perceived Effective Business Ethics through Leadership and Cultural Competence in the United States
}

\author{
http://doi.org/10.21272/bel.3(4).15-27.2019
}

Karina Kasztelnik, ORCID: https://orcid.org/0000-0002-1090-3700

PhD MBA, CPA, CTP, Senior Chair, Dissertation Research Committee, Grand Canyon University, College of Doctoral Studies, Washington, DC, U.S.

\section{Damon Brown}

Ed.D. MBA, Training Coordinator, Department of State, Arlington, VA, U.S.

\begin{abstract}
The paper summarizes the arguments and counterarguments within the scientific discussion on the issue perceived effective policing through leaderships' diversity training learning outcomes and cultural competence. The main purpose of this quantitative correlational study was conducted to address if and to what extent the leadership of law enforcement agencies is learning outcomes of diversity training initiatives and the level of cultural competence of leadership influences law enforcement organizational effectiveness. Systematization of literary sources and approaches for solving the problem of effective policing leadership indicates that this quantitative research study expands police leadership knowledge base by identifying whether significant differences exist in police effectiveness when incorporating diversity training initiative learning outcomes and cultural competence both exclusively and collectively. The relevance of the decision of this scientific problem is that police leadership possessing the knowledge and understanding police effectiveness through diversity training initiative learning outcomes and cultural competence can adapt and adjust in concert with the need to be more effective in Black and multicultural commutes based on the study's findings. The statistical significance indicated in this study concerning diversity training initiative learning outcomes predicting police effectiveness is substantial. The paper presents the results of this empirical analysis study that may contribute to the positive national senior management change by bringing into focus the role of effective policing through leaderships' diversity training learning outcomes and cultural competence and its positive impact on the public sector. Further research may be devoted to assessing the impact of financial indicators, the internal effectiveness of innovative technologies, motivation and customer service, etc. on the level of effectiveness of the professional activities of law enforcement agencies.
\end{abstract}

Keywords: Cultural Competence, Diversity Training, Management Effectiveness, Multicultural Leadership, Management Decision, Business Ethics.

JEL Classification: D83, D61, M1.

Cite as: Kasztelnik, K., Brown, D. (2019). Perceived Effective Business Ethics through Leadership and Cultural Competence in the United States. Business Ethics and Leadership, 3(4), 15-27. http://doi.org/10.21272/bel.3(4).15-27.2019.

(C) The Authors, 2019. This article is published with open access at Sumy State University.

\section{Introduction}

Policing in the United States, a democratic society is as straightforward as ensuring public order, keeping citizens safe and instilling trust while respecting their rights in principal insinuate an uncomplicated theory of policing. Although, a simple theory fails to address why the relationship between police and the community particularly Black and multicultural communities are poor and continue to decline. Theoretically, the police in a democratic society are empowered to maintain a satisfactory environment comprised of three common indicators of effective policing: order, security and public trust (Lai, 2013). The popular professional policing model briefly outlined above provides an overview of the core of democratic policing. Insomuch, it is clear that police are failing to be effective even under these fundamental principles. The events in Baltimore, Ferguson, Chicago, New York, and Cleveland, as well as the collective fallout from these developments, are substantial evidence that the violence and mistrust which, plagues community-police relationships across the nation has to addressed (Merkey, 2015).

Notwithstanding, the theory in which leadership's learning outcomes of diversity training initiatives and cultural competence have a statistically significant prediction on the organization forecast findings that 
ISSN (online) - 2520-6311; ISSN (print) - 2520-6761

revealed both learning outcomes of diversity training initiatives and cultural competence, individually but not collectively do predict a statistical significance on police effectiveness. However, previous to this research, it was not known if law enforcement leadership's learning outcomes of diversity training initiatives and cultural competence predict organizational effectiveness as there is an inconsistency between scholarship and the practical utility (Lopez-Littleton, \& Blessett, 2015; King, Dawson, Kravitz, \& Gulick, 2012).

\section{Background and Hypotheses}

The executive police leaders' pursuit of effectiveness has become increasingly more important in recent years and has turned to researchers to address their shortcomings. Since the 1900 s there has been widespread adoption of public sector management tools to measure the effectiveness of public sector organizations (Legrand \& Bronitt, 2012). In the 1980s organizational effectiveness became more prominent and changed to be a concept from the status of a construct (Ashraf, 2012). Police leaders continue to seek various methods and organizational strategies to increase effectiveness. Although for the police, it has been hard to describe what exactly constitutes organizational effectiveness (Kataria, Rastogi, \& Garg, 2013).

Traditionally, police have been influenced by societal constraints, insisting that their effectiveness measurements be in line with fighting crime. The societal constraints include to a great extent public perception. Kiehl (2013) found that good police leadership leading to effectiveness is largely based upon perception. Society does not expect that police will be able to prevent all crimes or contain all harms although; society does expect the police to provide the best protection possible (Sparrow, 2015). Low crime rates and a reduction in serious crimes may sway the perception of citizens to believe that police are being effective. Public and political definitions of police effectiveness demand that they solve crimes and put more criminals behind bars (Skogan, 1976). It has been the pursuit of this type of measurement, which has further eroded the relationship between police and the communities they serve. The dilemma of establishing measures leading to effectiveness and at the same time upsurge the relationship between police and community plague police leadership in today's society. The study developed productive measurements that increase public satisfaction and also improve police effectiveness. The more informative indicators of public satisfaction and confidence in the police while reducing crime are desired but harder to capture (Tiwana, Bass, \& Farrell, 2015).

Today it is seen as compulsory that communities be included in the formula when establishing what an effective police organization is. For the public, policing promises to become more effective, more responsive to the opinions of residents and less forceful, less brusque (Stone \& Travis, 2013). Additionally, with approximately 20,000 public police organizations in the United States, national coherence in American policing effectiveness would be a signal achievement (Stone \& Travis, 2013: 2). Learning how to address the issue of managing police for maximum effectiveness can be a noteworthy goal. Colbert, Barrick, and Bradley (2014) suggest that top executives charged with leading organizations expect that the leadership exhibited by them be related to organizational effectiveness. Often, it is the Black and multicultural communities whereas effectiveness eludes far too many police departments. Effective policing requires the trust of community members (Schlosser, Sundiata, Vaigoi, \& Neville, 2015). The dissatisfaction of minority communities diminishes police effectiveness as efficacy includes overall satisfaction of all constituents (Kiehl, 2013). Whereas, it is the lack of minority representation within the police that is the first drawback mentioned by diverse and multicultural communities. Researchers have examined how diversity representation can be used to benefit the police and increase police effectiveness. Researchers insist that service by diverse law enforcement officers has a significant value to them and the police agencies that employ them, as well as the communities they serve (Wilson \& Wilson, 2014). Others such as Fan (2016) and Woods (2014) suggest that many studies find that Black officers were tougher on minorities and act little or no different than Whites perhaps because of the socialization process into the role of the police. To this end, it may be more beneficial to address all officers regardless of race or ethnicity similarly and as police, employing diversity training in a concerted manner while ascertaining and addressing levels of cultural competence. There is an incomparable difference between diversity representation within an organization and diversity training initiatives. Diversity training initiatives defined as any program designed to facilitate positive intergroup interaction, reduce prejudice and discrimination while teaching others who are dissimilar how to work together (Lindsey, King, Hebi, \& Levine, 2015). Therefore, the benefits of diversity training fit into the overall concept of the effectiveness of police organizations internally and externally albeit mainly within Black and multicultural communities. Studies on racial diversity, valuing and managing diversity and business strategy showed that workforce diversity improves organizational efficacy and productivity (Ewoh, 2013). Assessing police leaders' cultural competence to conduct efforts to enhance it is also elemental in increasing the overall effectiveness of police organizations. Understanding a variety of cultures in addition to one's culture can improve effective interaction within Black, and multicultural communities that police are 
tasked and sworn to serve. Cultural competence can be used by police to creatively conduct police duties within the cultural restraints of the culture of that particular community. Cultural competence is an essential component in rendering useful and culturally responsive services to culturally and ethnically diverse communities (de Almeida Viera Monteiro, \& Fernandes, 2016). The police organization then reflects the cultural norms of Black and multicultural communities while engaging in their duties as police, ideally gaining approval and satisfaction within that community. However, previous to this research, it was not known if law enforcement leadership's learning outcomes of diversity training initiatives and cultural competence predict organizational effectiveness. Garib (2013) concluded that a more advanced study would advantageously include improved methodological activities resulting in some objective data concerning organizational outcomes of diversity training. While Carrizales, Zahradnik, \& Silverio, (2016) assert that future research may look at the integration of cultural competency into police organizations and its service delivery making it a more effective public administration. Furthermore, leadership's high level of diversity training initiative learning outcomes combined with a high level of cultural competencies relates to a higher level of law enforcement organizational effectiveness than either leadership's diversity training initiative learning outcomes or cultural competence alone. Diaz, Clarke, and Gatua (2015) suggest that research among interdisciplinary professionals is needed to identify and facilitate a more culturally competent and diversity educated workforce in order to possibly increase effective practices. There is and continues to be a gap relating to if law enforcement leadership's diversity training initiatives learning outcomes and cultural competence associated with predicting law enforcement organizational effectiveness. The target population for the study was AACPD in Maryland specifically, Sergeants Lieutenants, Captains, Majors, Commanders, Assistant Chiefs, Deputy Chiefs, and Chief.

Using multi-linear regression models, we hypothesize the following:

H1: Law enforcement leadership's diversity training initiatives learning outcomes do statistically significantly predict law enforcement organizational effectiveness.

H2: Law enforcement leadership's cultural competence does statistically significantly predict law enforcement organizational effectiveness.

We were able to derive the following research questions:

RQ1: To what extent do law enforcement leadership's diversity training initiatives learning outcomes predict law enforcement organizational effectiveness?

RQ2: To what extent do law enforcement leadership's cultural competence predict law enforcement organizational effectiveness?

\section{Research Design}

A quantitative correlational design was used to assess the relationships of diversity training initiatives learning outcomes and cultural competence to law enforcement organizational effectiveness. The target population for the study was AACPD in Maryland specifically, Sergeants Lieutenants, Captains, Majors, Commanders, Assistant Chiefs, Deputy Chiefs, and Chief. A multiple regression procedure is useful for finding which predictor variables should be in a multiple model regression (Zounemat-Kermani, Mohammad, Scholz, \& Miklas, 2014). Insomuch, a multiple regression was appropriate for examining the leadership of law enforcement agencies learning outcomes of diversity training initiatives and cultural competence of leadership predict law enforcement organizational effectiveness.

In this study, two predictor variables investigated, diversity training initiatives learning outcomes and cultural competence. Diversity training initiatives learning outcomes can be applied in various fashions such as training and encouraging, embracing and valuing diversity by police leadership. Although, it is most beneficial to understand diversity training initiatives learning outcomes in the traditional context of classroom training through an interactive lecture method, common in the policing profession. Hypothesized is when diversity training initiatives are realized as effective, increasing the performance of police cadets and particularly high ranking police leaders (Beu \& Nepravishta, 2013), diversity training initiatives learning outcomes will improve police effectiveness. The second predictor variable is the police leader's cultural competency, which was self-assessed to ascertain the ability for one to work effectively in cross-cultural situations. Then as well, mimicking leadership, a police agency's cultural competence can have a transformative effect on how organizational goals are successfully defined and achieved (Rice, 2007). Fittingly, for prediction and simulation tasks the techniques of multiple regressions are employed (Zounemat-Kermani et al., 2014). The focus of the study was to investigate the two predictor variables, cultural competence, and diversity training initiatives against the criterion variable law enforcement organizational effectiveness. The multiple regression analysis is suitable for this study. Regression analysis 
ISSN (online) - 2520-6311; ISSN (print) - 2520-6761

techniques are for predicting and simulating tasks (Zounemat-Kermani et al., 2014). A test for assumptions conducted where it found that all assumptions, sample size, normality, linearity, collinearity, multicollinearity, outliers, and homoscedasticity met. In a multiple regression study, it is also important to ensure that the model is valid. All three variables were deemed to be valid. The regression was then run through the SPSS statistical software revealing that RQ1, to what extent do law enforcement leadership's diversity training initiatives learning outcomes predict law enforcement organizational effectiveness was statistically significant. RQ2, to what extent do law enforcement leadership's cultural competence predict law enforcement organizational effectiveness was statistically significant.

\section{Sampling Procedures}

The general population for this study included full-time sworn law enforcement executives, supervisors, and managers (Sergeants, Lieutenants, Captains, Majors, Commanders, Assistant Chiefs Deputy Chiefs, and Chief) from Maryland specifically, AACPD. AACPD was chosen mainly because of its full time sworn officer to resident ratio parallels the sworn officer to resident ration in the majority of the nation and its availability and agreement to allow the research study. When attempting to obtain authorization to conduct the research for this study, the original police agency after agreeing months earlier refused to allow the study of their police leaders. After four months and contacting over 70 police agencies, the researcher was able to meet with two of the command staff of AACPD. The meeting with the command staff members was approximately 30 minutes as the research explained and consent was requested. It was after the Anne Arundel County legal section reviewed and allowed the study, the site authorization obtained. The overall population is sworn police leaders within the United States which, includes all ranks from Sergeant and above to the executive leader of a police agency, Chief. Although, the majority of police departments in the nation are composed of less than 50 officers (Reaves, 2015), the overall population for this study states with sworn officers in the range of 200-299 per 100,000 residents. Maryland's full time sworn officer to resident ratio is 283 per 100,000 residents (p. 16). According to Reaves (2015), this ratio falls in the range of 200-299 sworn officers per 100,000 residents making Maryland's sworn officer ratio in line with the majority of states ( 5 states plus the District of Columbia have more than 300 sworn officers, 11 states have less than 200 and 34 states have 200- 299 sworn officers), (Figure 2) suggesting that Maryland is comparable to most common sworn law enforcement officers to resident ratio in the nation but different than the rest of the nation's sworn officers per resident ration as the State of Maryland shares unique identifiers.

\section{Data Analysis and Test of Assumptions}

Despite the analysis mentioned earlier, before conducting the planned multiple regression analysis, the researcher checked the assumptions for the multiple linear regression model. Insomuch and as previously stated, the following assumptions were met and not violated; sample size, continuous variables, observation of independence, linearity, homoscedasticity, multicollinearity, outliers, and normality and normally distributed errors.

Sample size. For multiple regression one normally needs at least three variables, this study has three and a sample size of at least 20 is required. This study had 55 participants. The assumption test for sample size is easily met, see Table 1 above.

Continuous variables. The criterion variable, police effectiveness is continuous and is not categorical as are both predictor variables, diversity training initiatives learning outcomes, and cultural competence. In sum, all variables in this study are continuous.

Observation of independence. The assumption of independence of observation is essential when using regression analysis. This assumption heavily relies on the output of the Durbin-Watson test to ensure that there is no autocorrelation between the variables. Table 1 (Model summary) exhibits the output of the Durbin-Watson, 1.744. This falls within the range of 1.5 and 2.5 suggesting that the data is not autocorrelated. The assumption of independence of observation met.

Table 1. Model Summary

\begin{tabular}{|c|c|c|c|c|c|c|c|c|c|c|}
\hline \multirow[b]{2}{*}{ Model } & \multirow[b]{2}{*}{$\mathrm{R}$} & \multirow[b]{2}{*}{ R Square } & \multirow[b]{2}{*}{$\begin{array}{l}\text { Adjusted R } \\
\text { Square }\end{array}$} & \multirow[b]{2}{*}{$\begin{array}{l}\text { Std. Error of } \\
\text { the Estimate }\end{array}$} & \multicolumn{5}{|c|}{ Change Statistics } & \multirow[b]{2}{*}{$\begin{array}{l}\text { Durbin- } \\
\text { Watson }\end{array}$} \\
\hline & & & & & $\begin{array}{l}\text { R Square } \\
\text { Change }\end{array}$ & F Change & df1 & df2 & $\begin{array}{c}\text { Sig. F } \\
\text { Change }\end{array}$ & \\
\hline $\begin{array}{l}\text { Diversity } \\
\text { Training } \\
\text { Initiatives }\end{array}$ & $.790 \mathrm{~b}$ & .623 & .610 & 29.99233 & .045 & 6.529 & 1 & 55 & .013 & 1.744 \\
\hline Cultural Comp & $.761 \mathrm{a}$ & .579 & .571 & 31.43817 & .579 & 76.905 & 1 & 56 & .000 & \\
\hline
\end{tabular}

Note . Criterion Variable $=$ Police Effectiveness

Source: Complied by authors 
Linearity. To assess and meet the assumption of linearity, Figures 4 and 5 are presented to demonstrate linearity. Figure 1 expresses the linearity between the criterion variable, police effectiveness and the predictor variable diversity training initiative learning outcomes. Figure 1 also demonstrates the linearity between the criterion variable, police effectiveness, and the second predictor variable, cultural competence (notice reference lines). The scatterplot, Figure 2 indicates a random distribution of positive and negative residuals. The residual plot also indicates the positive and negative values across the entire range of the scatterplot given this scatterplot; there is no reason why the assumption of linearity not met. Although, the researcher tested the assumption of linearity by double-clicking on the scatterplot with the Chart Editor to reveal a reference line which was placed within the scatterplot using the Chart Editor toolbar. The researcher observed how one reference line creates an even divide between the entire field of the scatterplot, meeting the assumption of linearity.

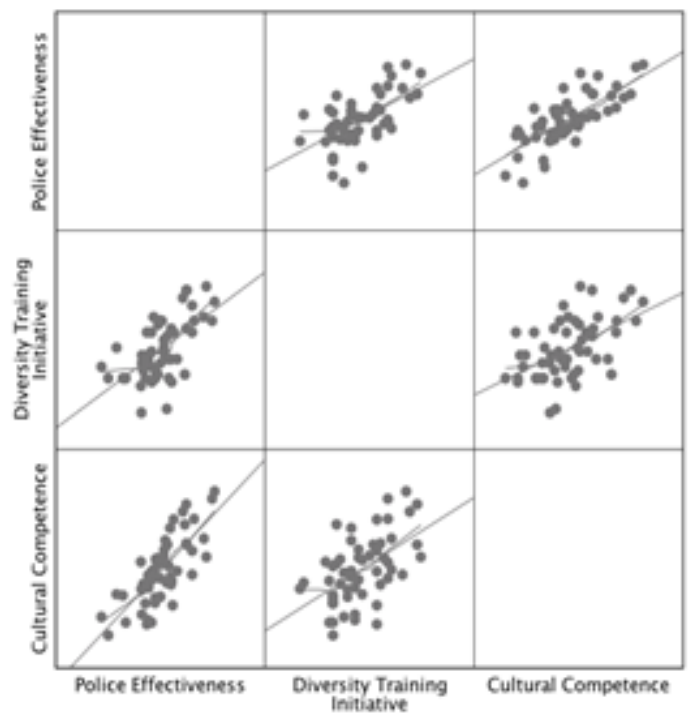

Figure 1. Scatterplot of predictor variables

Source: Complied by authors

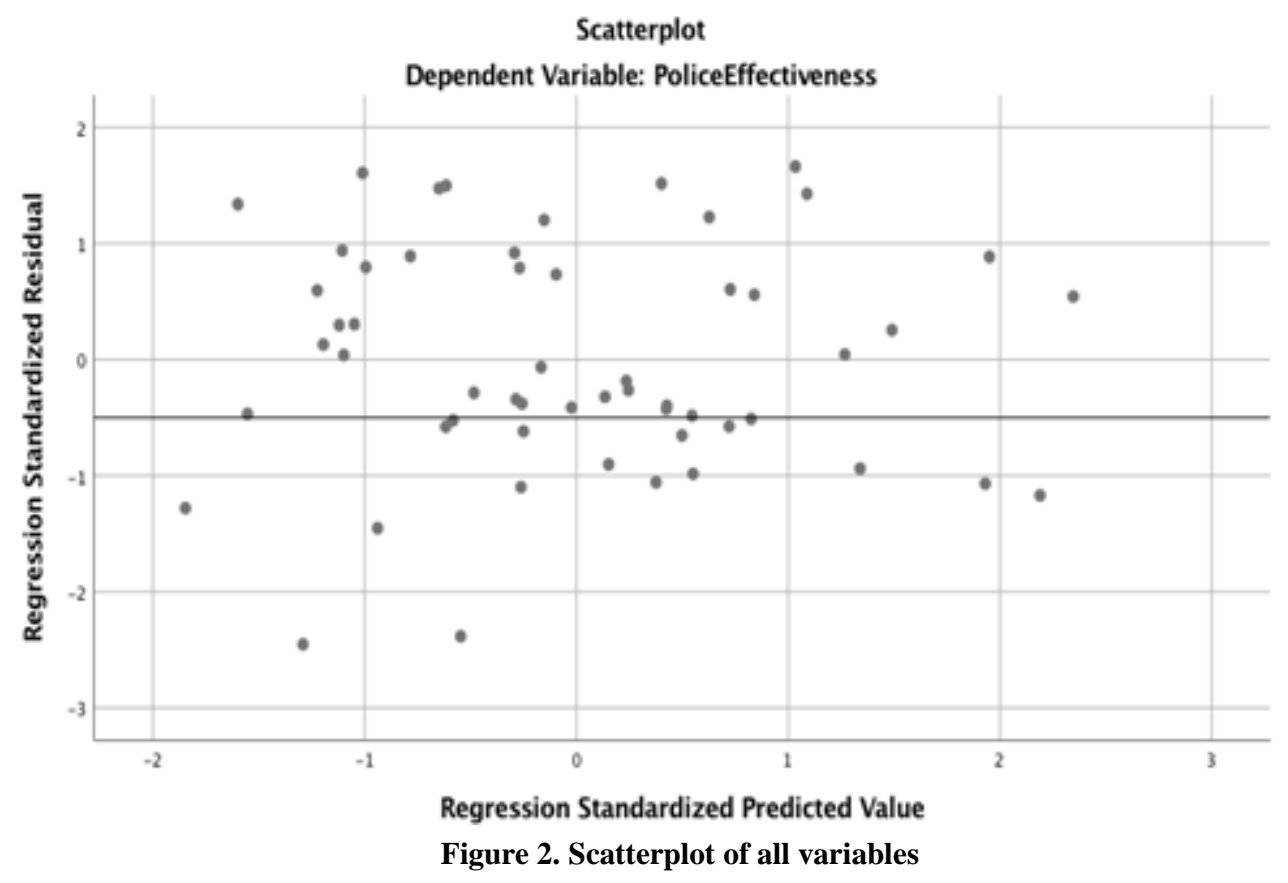

Source: Complied by authors 
ISSN (online) - 2520-6311; ISSN (print) - 2520-6761

Homoscedasticity. Figure 2 illustrates how the assumption of homoscedasticity met. The scatterplot with Regression Standardized Predictor Variable (X-Axis) and Regression Standardized Variable (Y-Axis) was analyzed to meet the assumption. Again, the researcher observed how one reference line creates an even divide between the half's meeting the assumption of linearity. The variances of residuals are constant. A more precise statistical assumption of homoscedasticity the researcher suggests referencing Breusch-Pagan or Koenker tests, both statistical analysis, which was not necessary for this assumption testing

Multicollinearity. The Correlation box (Table 2) referenced in search of predictors above .8 and a .2 or higher association between the predictor variable and the criterion variable both were in the proper range; .604 and .758 for both predictor variables diversity training initiative learning outcomes, and cultural competence, respectively. Furthermore, by observing the Durbin-Watson output, 1.744 within the range of .5 - 2.5, both predictors are significant and the VIF (Coefficients) 1.399 not being over ten, the assumption for multicollinearity met (Table 3). The researcher observed a significant finding when assessing multicollinearity between the two-predictor variables within the collinearity statistics. Notably, the Variance Inflation Factor (VIF) was 1.399 for both variables see Table 3. The score is slightly above the acceptable range of 1 . Therefore, the VIF, in this case, indicates a moderate association suggesting collinearity between the two-predictor variables, diversity training initiative learning outcomes and cultural competence. While the finding is compelling, collinearity in this instance does not produce an extremely large $R^{2}$ and, beta weights are statistically significant. The beta weights are in the proper direction and, removing one of the predictor variables does not result in an enormous change to the entire model.

Table 2. Pearson's Correlations

\begin{tabular}{|c|c|c|c|c|}
\hline & & Police Effectiveness & Diversity Training Initiative & Cultural Competence \\
\hline \multirow{3}{*}{ Police Effectiveness } & Pearson Correlation & 1 & $.604 * *$ & $.758 * *$ \\
\hline & Sig. (2-tailed) & & .000 & .000 \\
\hline & $\mathrm{N}$ & 55 & 55 & 55 \\
\hline \multirow{3}{*}{$\begin{array}{l}\text { Diversity Training } \\
\text { Initiative }\end{array}$} & Pearson Correlation & $.604 * *$ & 1 & $.556 * *$ \\
\hline & Sig. (2-tailed) & .000 & & .000 \\
\hline & $\mathrm{N}$ & 55 & 58 & 58 \\
\hline \multirow{3}{*}{ Cultural Competence } & Pearson Correlation & $.758 * *$ & $.556 * *$ & 1 \\
\hline & Sig. (2-tailed) & .000 & .000 & \\
\hline & $\mathrm{N}$ & 55 & 58 & 58 \\
\hline
\end{tabular}

Note. **. Correlation is significant at the 0.05 level (2-tailed)

Source: Complied by authors

Table 3. Coefficients

\begin{tabular}{|c|l|c|c|}
\hline \multicolumn{2}{|c|}{ Model } & \multicolumn{2}{c|}{ Collinearity Statistics } \\
\cline { 3 - 4 } & \multicolumn{2}{c|}{ Tolerance } & 1.399 \\
\hline \multirow{2}{*}{1} & Cultural Competence & .715 & .715 \\
\cline { 2 - 4 } & Diversity Training Initiative & .799 \\
\hline
\end{tabular}

Note. a. Criterion Variable: Police effectiveness

Source: Complied by authors

Outliers. Meeting the assumption for outliers, the Residual Statistics and Cook observed to ascertain that the Standard Residual was not too far to the left (-) or too far to the right (+). Outliers were not visually observed in the histogram and particularly the scatterplot, although four outliers observed in the box plot with the criterion police effectiveness (Figure 3). These outliers were not significant, meeting the assumption for outliers. Cook's was moderate to the left $(-2.452$, Table 4$)$, which would demonstrate the few outliers only found in the criterion variable, police effectiveness. Also, the regression model is valid through the observation of $R 2$, about both predictors .579 (diversity training initiative learning outcomes and .623 (cultural competence). 


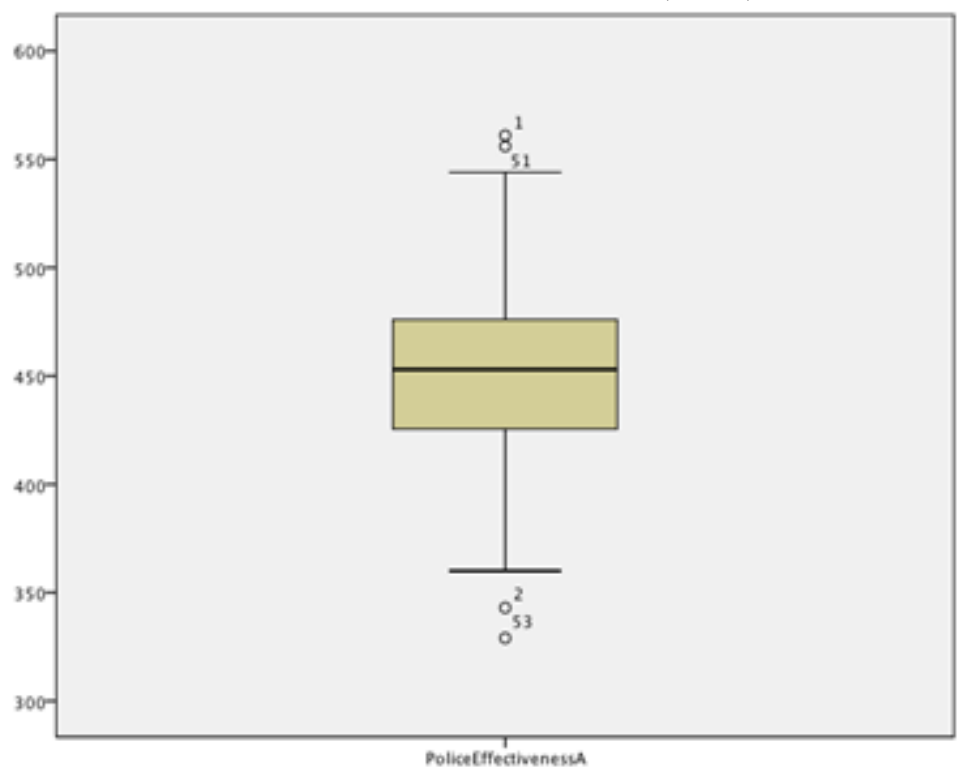

Figure 3. Box plot of criterion variable; Police Effectiveness with 4 outliers

Source: Complied by authors

Table 4. Residual Statistics

\begin{tabular}{|l|c|c|c|c|c|}
\hline & Minimum & Maximum & Mean & Std. Deviation & N \\
\hline Predicted Value & 381.7950 & 544.5240 & 453.4727 & 38.82082 & 55 \\
\hline Std. Predicted Value & -1.846 & 2.345 & .000 & 1.000 & 55 \\
\hline Standard Error of Predicted Value & 4.279 & 10.570 & 6.814 & 1.944 & 55 \\
\hline Adjusted Predicted Value & 385.5688 & 542.8939 & 453.2725 & 38.87580 & 55 \\
\hline Residual & -74.35873 & 50.40234 & .00000 & 29.75352 & 55 \\
\hline Std. Residual & -2.452 & 1.662 & .000 & .981 & 55 \\
\hline Stud. Residual & -2.523 & 1.768 & .003 & 1.012 & 55 \\
\hline Deleted Residual & -78.70632 & 57.02355 & .20019 & 31.65454 & 55 \\
\hline Stud. Deleted Residual & -2.667 & 1.806 & .001 & 1.030 & 55 \\
\hline Mahal. Distance & .094 & 5.581 & 1.964 & 1.682 & 55 \\
\hline Cook's Distance & .000 & .137 & .022 & .032 & 55 \\
\hline Centered Leverage Value & .002 & .103 & .036 & .031 & 55 \\
\hline
\end{tabular}

Note. a. Criterion Variable: Police Effectiveness

Source: Complied by authors

Normality and normally distributed errors. When testing for normality, focusing on Shapiro-Wilk (Table 5), the researcher noted if the statistical significance (Sig.) was above or below .05. This testing revealed that the Sig was above .05 for all three variables; police effectiveness (.447), diversity training initiative learning outcomes (.175), and cultural competence (.640), therefore, both predictor variables along with the criterion variable was normally distributed, see Table 5 . If the Sig. were lower than .05 the test for normality would have violated, and additional testing would have been necessary, contingent upon the sample size. The assumption test for normality met. Initially viewing the scatterplot, it illustrates the data points, which in this case normally distributed. Figure 2 emphasizes that the dots are scattered highlighting that the data meets the test of being normally distributed. Additionally, Figure 4 (normal P-P Plot) also emphasizes that the data points (dots) closely follow the diagonal line. Finally, Figure 5 (histogram) also illustrates a normally distributed line expressing that the data normally distributed. The data distribution is normal.

Table 5. Test of Normality

\begin{tabular}{|l|c|c|c|c|c|c|}
\hline \multirow{2}{*}{} & \multicolumn{3}{|c|}{ Kolmogorov-Smirnova } & \multicolumn{3}{c|}{ Shapiro-Wilk } \\
\cline { 2 - 7 } & Statistic & $\mathrm{df}$ & Sig. & Statistic & df & Sig. \\
\hline Police Effectiveness & .096 & 55 & $.200^{*}$ & .979 & 55 & .447 \\
\hline Diversity Training Initiative & .098 & 55 & $.200^{*}$ & .969 & 55 & .175 \\
\hline Cultural Competence & .067 & 55 & $.200^{*}$ & .983 & 55 & .640 \\
\hline
\end{tabular}

Source: Complied by authors 


\section{Normal P-P Plot of Regression Standardized Residual}

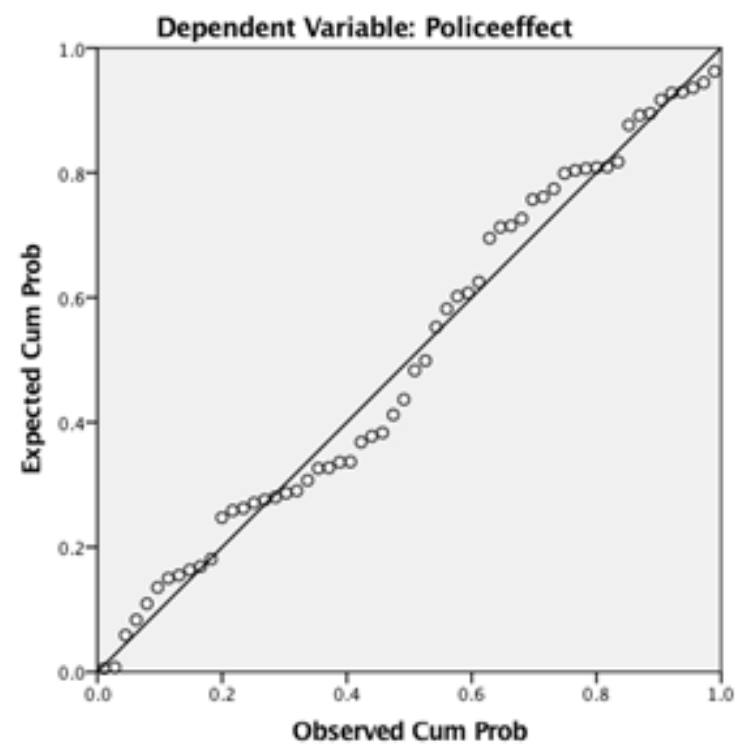

Figure 4. P-P Plot explaining the correlation of predictor variables diversity training initiative learning outcomes and cultural competence in relationship to criterion variable police effectiveness.

Source: Complied by authors

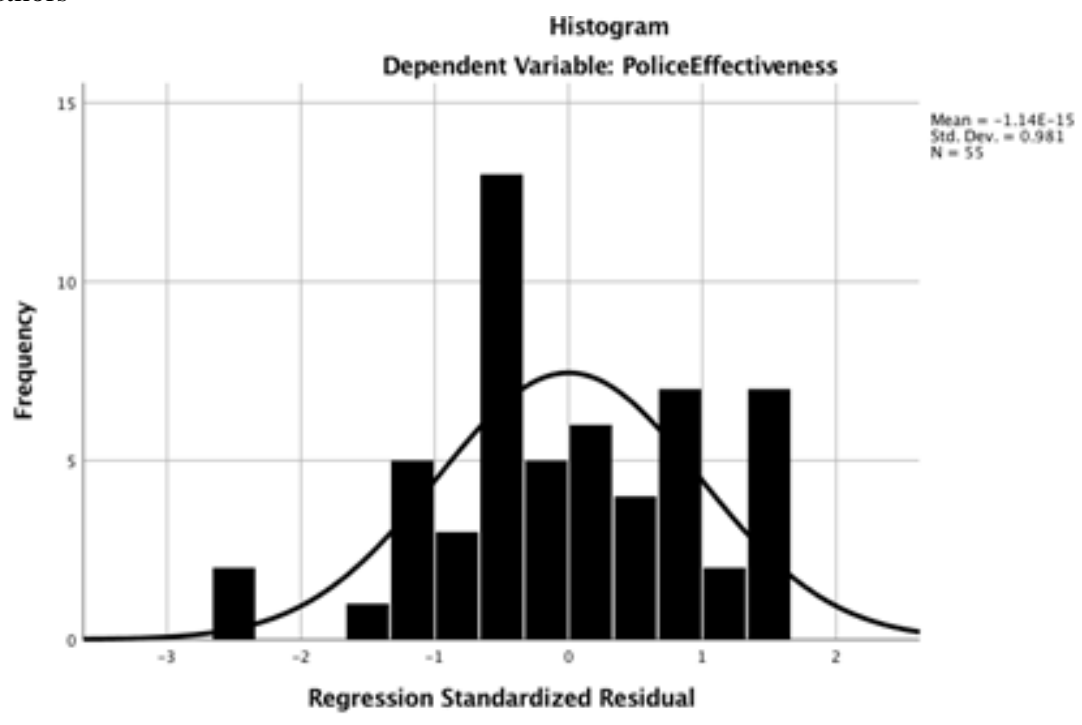

Figure 5. Histogram

Source: Complied by authors

Subsequently, several tests conducted including the developing of scatterplots, regression, and correlation analysis and subsequent diagnostics. All assumptions met, the researcher moved on to the multiple regressions with confidence.

\section{Results}

First research question and hypotheses testing results. The first and primary research question (RQ1) for this study was designed to determine to what extent, if any, law enforcement leadership's predictor variable, diversity training initiatives learning outcomes affects the criterion variable, law enforcement organizational effectiveness. Examining the first research question involved examination of means scores and utilization of multiple regression analysis. The hypotheses for the first research question were:

$\mathrm{H}_{0} 1$ : Law enforcement leadership's diversity training initiatives learning outcomes do not statistically significantly predict law enforcement organizational effectiveness.

H1: Law enforcement leadership's diversity training initiatives learning outcomes do statistically significantly predict law enforcement organizational effectiveness. Multiple regressions were calculated to understand the participants, police leaders; diversity training initiatives learning outcomes predict organizational effectiveness. 
A significant regression equation was found $(F(2)=30.426, p=.013)$, with $R^{2}$ of .610 . Participants predicted diversity training initiatives learning outcomes $\beta=.254$. Insomuch, for everyone to increase in standard deviation in the criterion variable, police effectiveness there is a .254 increase in the predictor variable, leader's diversity training initiative learning outcomes. Additionally, the independence of observation or Durbin-Watson test was found to be in the acceptable range 1.744 being close to 2.0 suggesting a positive correlation, however slight. The predictor variable leadership diversity training initiatives learning outcomes $p=.013$ is statistically significant. The results of RQ1 after the multiple regression analysis verified its statistical significance Sig. or $p$-value of .013 with the $p$-value remaining at a $95 \%$ confidence threshold. The $p$-value of .013 is $<0.05$, therefore, the predictor variable diversity training initiative learning outcomes is a significant predictor. The results rejected the null hypothesis in RQ1, see Table 7. For every one point of variance, it increases police effectiveness by $\beta .254$ (unstandardized coefficient) holding the other predictor variable fixed. The second research question and hypotheses testing results. The second research question (RQ2) for this study was designed to determine the effect if any of law enforcement leadership's predictor variable, cultural competence has on the criterion variable, law enforcement organizational effectiveness. Examining the first research question involved examination of means scores and utilization of a multiple regression analysis as this second research question does. The hypotheses for the second research question were:

$\mathrm{H}_{0}$ 2: Law enforcement leadership's cultural competence does not statistically significantly predict law enforcement organizational effectiveness.

H2: Law enforcement leadership's cultural competence does statistically significantly predict law enforcement organizational effectiveness.

Multiple regressions were calculated to understand the participants, police leaders; cultural competence predicts organizational effectiveness. A significant regression equation was found $(F(1)=76.905, p=.000)$, with $R^{2}$ of .571. Participants predicted cultural competence $\beta=.619$. Insomuch, for everyone to increase in standard deviation in the criterion variable, police effectiveness there is a .619 increase in the predictor variable, leaders' cultural competence. The predictor variable cultural competence $p=.000$ is statistically significant. The results rejected the null hypothesis. See Table 7.

Table 6. Regression Analysis Results with ANOVA

\begin{tabular}{|c|l|c|c|c|c|c|}
\hline \multicolumn{2}{|c|}{ Model } & Sum of Squares & df & Mean Square & F & S. Sig. \\
\hline \multirow{3}{*}{1} & Regression & 81381.009 & 2 & 40690.505 & 44.261 & $.000 \mathrm{~b}$ \\
\cline { 2 - 7 } & Residual & 47804.700 & 52 & 919.321 & & \\
\cline { 2 - 7 } & Total & 129185.709 & 54 & & & \\
\hline
\end{tabular}

Note. a. Dependent Variable: Police Effectiveness b. Predictors: (Constant), Diversity Training Initiative, Cultural Competence Source: Complied by authors

Table 7. Collinearity Diagnostics

\begin{tabular}{|c|l|c|c|c|c|c|}
\hline \multirow{2}{*}{ M. } & \multirow{2}{*}{ Dimension } & \multirow{2}{*}{ Eigen value } & \multirow{2}{*}{ Condition Index } & \multicolumn{3}{|c|}{ Variance Proportions } \\
\cline { 5 - 8 } & & & & (Constant) & Diversity Training Initiative & CC. \\
\hline \multirow{3}{*}{1} & Police Effectiveness & 2.982 & 1.000 & .00 & .00 & .00 \\
\cline { 2 - 7 } & Diversity Training Initiatives & .012 & 15.928 & .35 & .03 & .85 \\
\cline { 2 - 8 } & Cultural Competence & .006 & 22.634 & .64 & .97 & .15 \\
\hline
\end{tabular}

Note. Criterion Variable: Police Effectiveness. M=Model, CC.=Cultural Competence

Source: Complied by authors

The study does indicate that diversity-training initiative learning outcomes did positively affect police effectiveness (RQ1). In policing it may be beneficial to understand that it is the learning outcomes of diversity training and other diversity initiatives that are substantial, as simple diversity training has existed in policing since after the Civil Rights Era, the late 60s and early 70s. In short, it suggested that effective diversity training initiatives and the learning outcomes stemming from such produces desired behavioral change. This behavioral change can then apply to and throughout communities, which are different by and through first-line supervisors, or Sergeants, substantially represented in this study. The results of RQ2 after the multiple regression analysis verified its strong statistical significance Sig. or $p$-value if .000 with the $p$ value remaining at $95 \%$ confidence threshold. The $p$-value of .000 is $<0.05$, therefore, the predictor variable cultural competence is a significant predictor. The results rejected the null hypothesis in RQ2. For every one point of variance, it increases police effectiveness by $\beta .545$ (Unstandardized coefficient) holding the other 
ISSN (online) - 2520-6311; ISSN (print) - 2520-6761

predictor variable fixed. The study may suggest that increasing the cultural competence of police allows police to be more effective if they solve police problems in specific cultures within those cultural constraints of that particular community, albeit Black and multicultural communities. Consequently, adhering to cultural constraints within said communities may also enhance community member acceptance of police practices. Acceptance of police operations within Black and multicultural communities can, therefore, be deemed effective policing and very well bring the police closer to the community and the community closer to the police addressing a huge objective.

Table 8. Coefficients Subsequent to Regression Analysis

\begin{tabular}{|c|c|c|c|c|}
\hline \multirow{2}{*}{ Model } & Unstandardize & Coefficients & Standardized Coefficients & \multirow[b]{2}{*}{ Sig } \\
\hline & B & Std. Error & Beta & \\
\hline a. Police Effect (Constant) & 157.152 & 34.458 & & .000 \\
\hline b. Diversity Training Initiative & 1.515 & .593 & .254 & .013 \\
\hline c. Cultural Competence & .545 & .088 & .619 & .000 \\
\hline d. Police Effect (Constant) & 214.419 & 27.435 & & .000 \\
\hline e. Cultural Competence & .670 & .076 & .761 & .000 \\
\hline
\end{tabular}

Note. a. Constant or Criterion Variable: Police Effectiveness

Source: Complied by authors

In sum, the importance of answering the research questions has the utmost significance in this study. Diversity training initiatives learning outcomes and cultural competence do increase police effectiveness. Both of these predictor variables, diversity-training initiatives learning outcomes and cultural competence are statistical significance .013 and .000 respectively. Figure 2 displays a strong positive correlation with the multiple regression analysis conducted.

\section{Discussion}

\section{Theoretical and Practical Implications}

The research took into consideration that a significant problem in policing is the weak relationship between community and police. Some Black and multicultural communities still see the police as the enemy (Woods, 2014). The first research question examined if diversity-training initiative learning outcomes predict police effectiveness. What conducted above was done to evaluate whether or not the presence of diversity training initiatives learning outcomes could predict police effectiveness. The results of the study indicate that there are statistical significance and support for diversity training initiative learning outcomes predicting police effectiveness. An initial observation of the results suggests an educative effect and benefit in increasing diversity initiatives, which generate effective learning outcomes of police leadership.

The second research question examined if cultural competence predicted police effectiveness. The question above was to evaluate whether or not the presence of cultural competence could predict police effectiveness. The results of the study indicate that there is statistical significance and subsequent support that cultural competence effects police effectiveness. An initial observation of the results suggests that there is an educative effect in increasing cultural competence of police leadership modifying behavior which directly relates to Black and multicultural communities leading to effectiveness. From a theoretical viewpoint, both research questions met the expected hypothesis. As a result, diversity training initiative learning outcomes and cultural competence involve enhancing education at least in the sense of additional learning related to what police leaders may or may not know about diversity initiatives and cultural competence. Learning about a police problem and developing a theory to address that problem is well within the confines of the theoretical research and four questions put forth by Eck (2003). It is likely that the results of the two research questions can be shared throughout the nation to increase police effectiveness as explained in Chapter 3 based on the ratio of police agencies sworn officers to 100,000 residents although, all police departments have unique problems and other factors which also must be considered. Police leadership nationwide can learn from this study and subsequent problem solving; increasing systematic information exchange among police agencies is part of the answer (Eck, 2003). From a practical viewpoint, the results of the research questions we somewhat expected. This study acted upon three different studies suggestions for research, which outlined that the results of such a study, this research study would have significant implications on police leaders and the policing profession as a whole. Garib (2013), Carrizales et al. (2016) and, Diaz et al. (2015) call for additional research. Garib (2013) concluded that a more advanced study would advantageously include improved methodological activities resulting in some objective data concerning organizational outcomes of diversity training, Carrizales et al. (2016) asserted that future research may look 
at the integration of cultural competency into police organizations and how its service delivery will make it a more effective public administration and, Diaz et al. (2015) suggest that research among interdisciplinary professionals is needed to identify and facilitate a more culturally competent and diversity educated workforce in order to possibly increase effective practices.

\section{Conclusions}

Lopez-Littleton and Blessett (2015) stressed that there is an inconsistency between scholarship and the practical utility of how diversity training and cultural competence predict effectiveness. More research is needed to examine the direct causal link between the learning outcomes resulting from diversity training with organizational effectiveness (King et al. (2012). Research is limited to examining cultural competence from healthcare, education and social work perspectives that ignore the complexity of the police profession (Elton, 2013). Significantly, Woods (2014) may have pinpointed the importance of this research when he mentioned that it was uncertain exactly how diversity training initiatives learning outcomes and level of cultural competence lead to if at all, effective policing. This research sought to answer questions related to police leadership and organizational effectiveness to further the police profession and its relationship with communities, Black and multicultural communities. Results from this quantitative research study expand the police leadership knowledge base by identifying whether significant differences exist in police effectiveness when incorporating diversity training initiative learning outcomes and cultural competence both exclusively and collectively.

Performance measures that include measures relevant to satisfying citizens and enhancing police organizational legitimacy can predict police effectiveness (Knight, 2014). Knight's explanation of influencing police effectiveness fits into the foundational theory of CPT by addressing the overall problem of the abhorrent relationship between the police and community principally, Black and multicultural communities. Knight's statement concerning police effectiveness also addresses the inclusion of citizen concerns, perception, satisfaction, legitimacy and trust of the police are at the forefront. Police leadership possessing the knowledge and understanding police effectiveness through diversity training initiative learning outcomes and cultural competence can adapt and adjust in concert with the need to be more effective in Black and multicultural commutes based on the study's findings. A summary of the findings and relevance to policing is summarized below; the statistical significance indicated in this study concerning diversity training initiative learning outcomes predicting police effectiveness is substantial. Not only does it mean that the broad and inclusive definition of diversity is paramount in the pursuit of police effectiveness as explained in the literature review, but diversity in the 21 st century goes well beyond Black and multicultural communities. In this sense, police leaders must begin to understand the definition of diversity in this current time frame to be able to engage in effective learning, which then results in diversity training learning outcomes. This may be the "what" in the first question presented in the study's foundational theory, the CPT (what are the problems?). Is it possible that police leaders do not understand what diversity is in the 21 st century? To strive for police effectiveness, police leaders must know how to define diversity in this facepaced world we lie in today. Police using traditional academies may be in question. In the pursuit of police effectiveness through the statistically significant predictor, diversity training initiative learning outcomes suggest that effective training and learning must take place. Limiting these shortcomings, we would allow police to achieve the above observations resulting in a behavioral change in police leaders particularly in respect to diverse individuals who for the most part reside in Black and multicultural communities. This study offers that behavioral change stemming from effective diversity training initiatives learning outcomes leads to police effectiveness.

Police leaders must attempt to increase cultural competence in pursuit of police effectiveness through blended learning theories. It is also plausible that police learning is not up to par, because they have not moved forward from traditional learning. It may be that the lack of experiential learning, learning by gaming and other more recent adult learning theories has not been realized by traditional police academies. The reasons presented above indicate some of the problems concerning why policing has had the shortcomings discussed in this study obtaining police effectiveness by way of statistically significant diversity training initiative learning outcomes and cultural competence. From the study's findings we also understand that the last research question; to what extent do law enforcement leadership's high level of diversity training initiative learning outcomes and high level of cultural competences predict to higher level of law enforcement organizational effectiveness than either leadership's diversity training initiative learning outcomes or cultural competence alone, resulted in the acceptance of the null hypothesis. While this last finding was interesting, it does not affect the study in a negative fashion. The above findings and realizations 
Business Ethics and Leadership, Volume 3, Issue 4, 2019

ISSN (online) - 2520-6311; ISSN (print) - 2520-6761

lend themselves to the last question of the CPT. How can we learn from problem solving? The findings above pointed out some very important aspects of definitions, training and behavioral change from addressing problem solving in the pursuit of effective policing. While this study finds support for police leaders to consider diversity training initiative learning outcomes and cultural competence and it predicts police effectiveness, overall organizational effectiveness hinges on the specific organization mission, vision, and values of the specific police agency. Reynoso and Tovar (2014) asserted that if there are some validated and credible variables related to the effectiveness of police agencies, then the hypothesis that there are other and additional organizational variables related to the effectiveness of the police is accepted. Both research questions are found to have statistical significance whereas rejected are two null hypotheses. The findings of AACPD respondents strongly suggest and find support for emphasizing the two predictor variables to increase the effectiveness of their police agency principally in Black and multicultural communities.

\section{Recommendation for the Future Study}

Future researchers could also look deeper into police effectiveness including other variables that are readily acceptable to Black and multicultural communities. Ongoing relationships with key members of the community including standardized reporting systems developed with the community, infusing civilians from Black and multicultural communities into critical operational positions within the police department along with other procedures, techniques, and reporting systems that consider the community. Future recommendations for research would then be to conduct studies in the context of professional organizational effectiveness employing aspects such as; growth, resource acquisition and capabilities, financial performance, internal efficiency, roles of leadership, innovative technology, motivation and customer service, which are inclusive of a comprehensive systems approach and not typical or exclusive to only police professions. If policing is to move forward police leaders must steer their organizations to more professional and national acceptable standards that also include the flexibility and range of effectiveness that addresses communities that are different such as Black and multicultural communities. Seeking police effectiveness cannot be a one size fits all remedy. Researchers must examine how to increase organizational effectiveness in the methods mentioned above to continue to launch policing into the 21 st Century.

\section{References}

1. Ashraf, G. (2012). A review on the models of organizational effectiveness: A look at cameron's model. International Education Studies, 5(2), 80. Doi:10.5539/ies.v5n2p80.

2. Beu, A., \& Nepravishta, A. (2013). Relationship between the police educational formation system and public security. European Journal of Sustainable Development, $2(4), 173$. https://doi.org/10.14207/ejsd.2013.v2n4p173.

3. Carrizales, T., Zahradnik, A., \& Silverio, M. (2016). Organizational advocacy of cultural competency Initiatives: Lessons for public administration. Public Administration Quarterly, 40(1), 126.

4. Choi, H., Suh, E. E., Park, C. G., Park, J., \& Fernandez, E. (2015). Reliability and validity of a Korean version of the cultural awareness scale (K-CAS). Korean Journal of Adult Nursing, 27(4), 4479. https://doi.org/10.7475/kjan.2015.27.4.472.

5. Colbert, A. E., Barrick, M. R., \& Bradley, B. H. (2014). Personality and leadership composition in top management teams: Implications for organizational effectiveness. Personnel Psychology, 67(2), 351. Doi:10.1111/peps.12036.

6. De Almeida Vieira Monteiro, A.T., \& Fernandes, A. B. (2016). Cultural competence in mental health nursing: Validity and internal consistency of the Portuguese version of the multicultural mental health awareness scale--MMHAS. BMC Psychiatry, 16. Doi: 10.1186/s12888-016-0848-z.

7. Diaz, C., Clarke, P. N., \& Gatua, M. W. (2015). Cultural competence in rural nursing education: Are we there yet? Nursing Education Perspectives, 36(1), 22. Doi: 10.5480/12-1066.1.

8. Eck, J. E. (2003). Police problems: The complexity of problem theory, research and evaluation. Crime prevention studies, 15, 79-114.

9. Elton, J. S. (2013). An explanatory study of cultural competence: Examining cross-cultural adaptability in peace officers (Doctoral dissertation, University of Akron).

10.Ewoh, A. I. (2013). Managing and valuing diversity: Challenges to public managers in the 21 st century. Public Personnel Management, 42(2), 107-122. Doi: 10.1177/009 1026013487048.

11.Fan, M. D. (2016). Violence and police diversity: A call for research. Brigham Young University Law Review, 2015(4), 875-914. Available at: https://digitalcommons.law.byu.edu/lawreview/vol2015/iss4/4.

12. Garib, G. (2013). Diversity is in the eye of the beholder. The Psychologist-Manager Journal, 16(1), 1832. Doi: $10.1037 / \mathrm{a} 0094733$.

13. Giacobbi, P. R. (2002). Survey construction and analysis, Part II: Establishing reliability and validity. Athletic Therapy Today, 7(5), 60-61. Doi: 10.1123/att.7.5.60. 
14.Glickman, L. B., Olsen, J., \& Rowthorn, V. (2015). Measuring the cross-cultural adaptability of a graduate student team from a global immersion experience. Journal of Cultural Diversity, 22(4), $148-54$. Doi:10.1016/j.physio.2015.03.3241.

15. Kataria, A., Rastogi, R., \& Garg, P. (2013). Organizational effectiveness as a function of employee engagement. South Asian Journal of Management, 20(4), 56-73. Retrieved from: https://lopes.idm.oclc.org/login?url=http://search.proquest.com/docview/1519059074?accountid=7374.

16.Kiehl, K. R. (2013). Examining perceptions of organizational effectiveness of police departments and leadership styles of police supervisors (Order No. 3569890). Available from: ProQuest Dissertations \& Theses Global. (1370761178). Retrieved from https://lopes.idm.oclc.org/login?URL=http://search. proquest.com/docview/1370761178?accountid=7374. DOI: 10.1108/PIJPSM-03-2013-0028.

17.King, E., Dawson, J., Kravitz, D., \& Gulick, L. (2012). A multilevel study of the relationships between diversity training, ethnic discrimination and satisfaction in organizations. Journal of Organizational Behavior, 33(1), 5-20. Doi: 10.1002/job.728.

18. Knight, G. M. (2014). Calls for service and police effectiveness: The role of performance measurement systems. Thesis (PhD Doctorate), Griffith University, Brisbane. Retrieved from: https://www120.secure.griffith.edu.au/rch/items/06938197-1233-40da-aeb1-c33b6235c6ab/1/.

19.Lai, Y. (2013). Policing diversity: Determinants of White, Black, and Hispanic attitudes toward police. El Paso, TX: LFB Scholarly.

20.Legrand, T., \& Bronitt, S. (2012). Policing to a different beat: Measuring police performance. In policing and security in practice (pp. 1-19). Palgrave Macmillan UK. https://doi.org/10.1057/9781137007780_1.

21.Lindsey, A. A., King, E., Hebi, M., \& Levine, N. (2015). The impact of method, motivation, and empathy on diversity training effectiveness. Journal of Business \& Psychology, 30(3), 605-617. Doi:10.1007/s10869-014-9384-3.

22.Lopez-Littleton, V., \& Blessett, B. (2015). A framework for integrating cultural competence into the curriculum of public administration programs. Journal of Public Affairs Education, 21(4), 557-574. https://doi.org/10.1080/15236803.2015.12002220.

23. Merkey, L. (2015). Building trust and breaking down the wall: The use of restorative justice to repair police-community relationships. Missouri Law Review, 80(4), 1133 . Available at: http://scholarship.law.missouri.edu/cgi/viewcontent.cgi?article=4171\&context=mlr.

24.Okoro, O., Odedina, F., \& Smith, W. T. (2015). Determining the sufficiency of cultural competence instruction in pharmacy school curriculum. American Journal of Pharmaceutical Education, 79(4), 116120. Doi: 10.5688/ajpe79450.

25.Reaves, B.A. (2015). Local police departments, 2013: Personnel, policies and practices. Washington, D.C.: U.S. Department of Justice. Available at: http://www.bjs.gov/index.cfm?ty=pbdetail\&iid=5279.

26. Reynoso, L. F., \& Tovar, L. A. (2014). Organizational variables in effectiveness of police. International Review of Management and Business Research, 3(2), 827. Available at: http://citeseerx.ist.psu.edu/viewdoc/download?doi=10.1.1.679.8358\&rep=rep1\&type=pdf.

27.Rice, M. F. (2007). Promoting cultural competency in the public administration and public service delivery: Utilizing self-assessment tools and performance measures. Journal of Public health Affairs Education, 13, 41-57. Doi:10.1080/15236803.2007.12001466.

28.Schlosser, M., Sundiata, C. J., Vaigoi, M., \& Neville, H. (2015). Improving policing in a multicultural society in the United States: A new approach. International Journal of Criminal Justice Sciences, 10(1), 115-121. Available at: http://www.ijcjs.com/pdfs/schlosseretalijcjs2015vol10issue1.pdf.

29.Skogan, W. G. (1976). Efficiency and effectiveness in big-city police departments. Public administration review, 36, 278-286. Available at: http://skogan.org/files/Efficiency_and_Effectiveness_in_BigCity_Police_Departments2.pdf.

30.Sparrow, M. K. (2015). Measuring performance in a modern police organization. Psychosociological Issues in Human Resource Management, 3(2), 17-52. Available at: https://www.addletonacademicpublishers.com/search-in-pihrm/2493-measuring-performance-in-amodern-police-organization.

31.Stone, C., \& Travis, J. (2013). Toward a new professionalism in policing. Journal of the Institute of Justice and International Studies, 13, B1.

32. Tiwana, N., Bass, G., \& Farrell, G. (2015). Police performance measurement: An annotated bibliography. Crime Science, 4(1), 1-28. Doi: http://dx.doi.org/10. 1186/s40163-014-0011-4.

33. Woods, S. (2014). Does the race of police officers' matter? Police officers on interactions with citizens and police procedures (Order No. 3665295). Available from ProQuest Dissertations \& Theses Global. (1637644197).

Retrieved

from https://lopes.idm.oclc.org/login?url=http://search.proquest.com/docview/1637644197?accountid=7374.

34.Wilson, C. P., \& Wilson, S. A. (2014). Are we there yet? Perceptive roles of African American police officer in small agency settings. Western Journal of Black Studies, 38(2), 123-133.

35.Zounemat-Kermani, Mohammad, Scholz, \& Miklas. (2014). Modeling of dissolved oxygen. Applying stepwise regression and a template-based fuzzy logic system. Journal of Environment Engineering, 140, 69-76. Doi: 10.1061/(ASCE)EE.1943-7870.0000. 